\title{
TWO LEGS POLICY \\ (Indonesian Covid-19 Case Study)
}

\author{
By : \\ Endang Naryono \\ LECTURER OF STIE PASIM SUKABUMI \\ rtumarima@gmail.com
}

\begin{abstract}
ION
The national covid-19 vaccination program carried out is still on a limited scale and is still below the target set by the government, especially compared to the population in Indonesia, this has resulted in the very highest Covid-19 growth rate, even the highest in Southeast Asia with one of the highest mortality ratios in the world in above $2.5 \%$. The obstacle faced by the government is the limited number of vaccines imported from China, Europe and America, which incidentally are countries affected by COVID-19. then the uneven distribution of the covid-19 vaccine, this is due to the wide area of the country with uneven infrastructure facilities so that not all vaccinations can be carried out in sub-districts or out of town. This results in the low number of people being vaccinated and the last is the lack of socialization, education and training. distribution of information about the importance of being vaccinated against covid-19 so that many people refuse to be vaccinated, and do not understand the importance and benefits of having a vaccine for covid-19. This is a big gamble for Indonesia in dealing with COVID-19, which is getting more and more frightening with the discovery of a new variant resulting from a mutation that is much more deadly. This covid-19 vaccination is an absolute must and must be successful because if this fails it will result in a frightening humanitarian disaster, breaking the chain of distribution with strict rules and sanctions against the community in implementing the Health protocol must be carried out continuously and continuously
\end{abstract}

Keywords: Indonesia's covid-19 vaccination

\section{PRELIMINARY}

The COVID-19 pandemic has been going on for almost two years. The SARS-Cov-2 virus that causes COVID-19 also mutates and gives rise to new variants that are more dangerous and threaten safety. By recognizing the variants of the COVID-19 virus, both new and old, and understanding the symptoms and ways to prevent transmission, the community will suppress the spike in cases that have occurred recently in the country, which is increasing and worrying. This COVID-19 virus is easy to change, there are two variants of concern, namely the Alpha (B.1.1.7) and Delta (B.1.617) variants. But in addition to the mutation of the virus, the spike in cases is also due to crowds, which are carried out by undisciplined people's behavior and the lack of firmness of government officials in enforcing regulations regarding health protocols.

The COVID-19 vaccine itself has been researched and is still effective against variants of the COVID19 virus, especially Alpha and Delta. The acceleration of vaccination by the government is one solution in suppressing the growth of the spread of Covid-19 in the country. Because for example, with only $40-50 \%$ COVID-19 vaccination coverage in European countries, they have dared to hold 
the 2021 European Cup, so that national vaccinations must be carried out continuously. The main obstacle in this COVID-19 vaccination is the limited availability of stock so that the ratio between vaccination and population is still small. The national vaccine in collaboration with Sinovac from China is still in clinical trials so the benefits cannot be felt.

If infected with this virus, the consequences are fatal so we must really avoid it. Apart from being disciplined in enforcing the $5 \mathrm{M}$ protocol, to complete it we must be vaccinated. Sufficient government budget in providing vaccines, equitable and effective distribution and public awareness to be vaccinated are the keys to suppressing the growth rate of this Covid-19 virus. The COVID-19 vaccine is considered to have been effective in providing the required level of protection. Even if they are infected, if they have received vaccinations, they will reduce symptoms of illness and the risk of death for COVID-19 patients. So people should not be afraid of being vaccinated but should be happy because they have immunity to the Covid-19 virus. Educate the public about the dangers of COVID-19. with the current facts, the number of illnesses and deaths due to COVID-19, the public must start to realize the importance of health protocols and vaccinations

The current condition is an alarm for individuals and the surrounding environment so that we strengthen health protocols in offices, settlements, shopping centers, to villages in remote areas. The government must be able to empower resources down to the villages to influence changes in community behavior. Activate gotong royong in the community and create an independent isolation room at the community level. This is an effort that can ease the burden on our hospitals, which are currently starting to fill up, especially on the island of Java. Seeing the developments in June 2021 is so scary with the positive spike in Covid-19 in Indonesia, especially on the island of Java. So the government must be vigilant by setting strict and firm rules in the Health protocol.

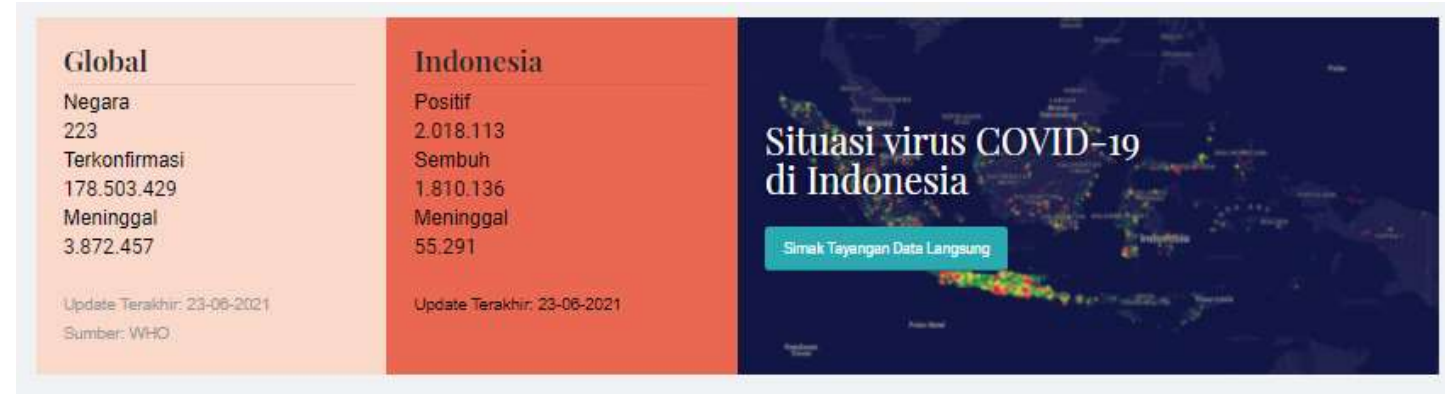

Table. 1

World and Indonesia Covid-19 Development Table In 2021

Source: https://covid19.go.id/

Globally, positive cases of COVID-19 have decreased, especially in European, American and East Asian countries such as Japan, South Korea, while in Southeast Asia, where the positive growth rate for COVID-19 is very small, Singapore and Vietnam. Meanwhile, Indonesia still has high case growth compared to Southeast Asian countries. The very large population approaching 300 million, the limited budget allocation for handling Covid-19, the vast territory of the country that spans 2 million $\mathrm{km}$ and the low level of public awareness in the Health protocol are a very difficult task for the current government.

Seeing the conditions Indonesia is currently facing, the best way to break the chain of transmission of COVID-19 is to prevent it. The best way to prevent transmission is to avoid mass crowds. The 
Committee for Handling COVID-19 and National Economic Recovery (KPCPEN) was formed in the context of accelerating the handling of COVID-19 as well as economic recovery and national economic transformation. KPCPEN's priorities in order are: Healthy Indonesia, realizing safe people from COVID-19 and reforming health services; Indonesia Works, realizing empowerment and acceleration of labor absorption; and Indonesia Grows, realizing the recovery and transformation of the national economy. In its implementation, KPCPEN is assisted by the COVID-19 Handling Task Force and the National Economic Recovery and Transformation Task Force. (Source: https://covid19.go.id/)

\section{COVID-19 IN INDONESIA}

\section{The Development of the Spread of Covid-19 in Indonesia}

The growth of Covid-19 in its second year has not shown any signs of slowing down, even for three weeks in April 2021, the growth that was exposed was so frightening. Even though the government has carried out a national program of covid-19 vaccination for the community, it has not been able to suppress its growth rate, it is even increasing with a death rate ratio of one of the highest in the world at $2.7 \%$. The latest phenomenon is the high number of children who are positive for COVID19, especially in the nation's capital, Jakarta, which has the highest Covid-19 growth nationally, where one in 10 positive for COVID-19 is a child.

\section{Peta Sebaran COVID-19}

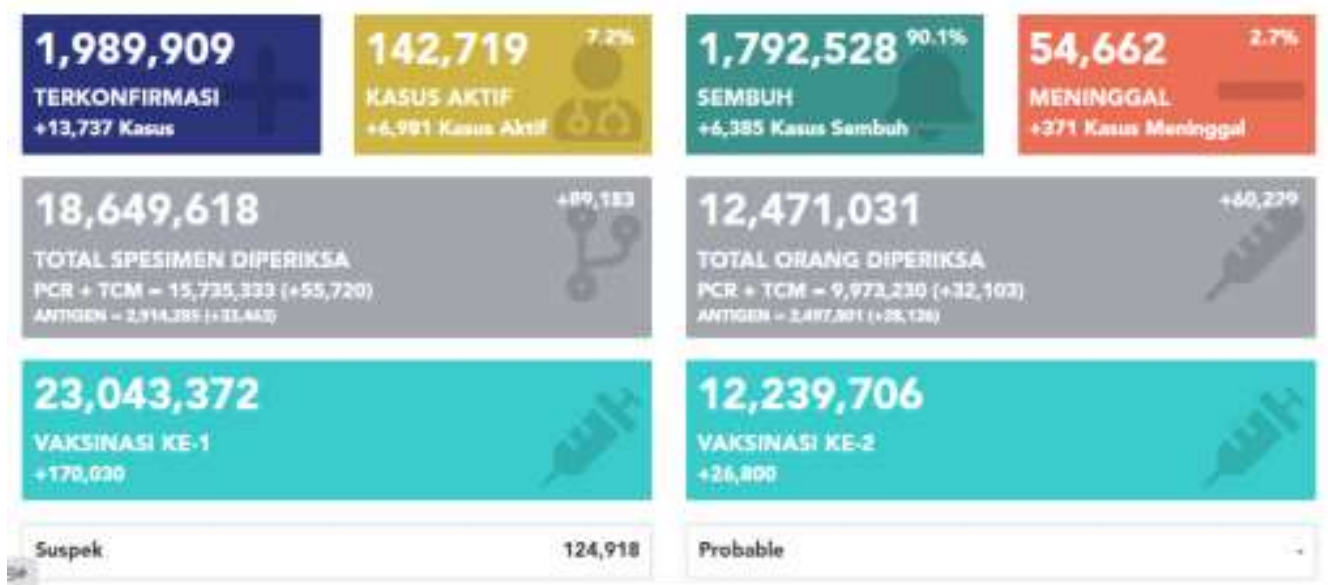

Tables. 2

2021 COVID-19 Distribution Map

Source: https://covid19.go.id/peta-sebaran-covid19

The number who were exposed to Covid-19 until the third week of April was approaching 1,989,909 people, a very large number, with a recovery rate of $90.1 \%$ or $1,7092,528$ people and a death rate of $2.7 \%$ or 54,662 people. the cure rate is very encouraging because it has a high ratio, it's just that the mortality ratio is a warning because it is very worrying to be one of the highest in the world. Vaccinations that have been carried out nationally are only for a limited scale, namely civil servants, 
military, police and teachers, lecturers and the elderly. So the ratio is still small compared to the number of Indonesians in the third week of June 2021 who had the first vaccination, namely 23.1 million people, who had received the second vaccination was 12.5 million people, a number that is still small compared to the government's target. at 181.5 million people. So that there is no other way for the government to speed up the vaccination process until the end of this year by using all available resources so that it can reduce the growth rate of COVID-19 and break the chain of spread in the country.

\section{Progress of Covid 19 Confirmed Cases per day}

The development of Indonesia's Covid-19 during these 2 years has very high growth, touching 2 million people, the recovery ratio is $90 \%$ with a death ratio of $2.7 \%$. growth exposed to a progressive increase, even in April and May 2021, the number of those who recovered and those who were positive for COVID-19 was higher. This has resulted in the need for health facilities and infrastructure to increase amid the limited number of health personnel.

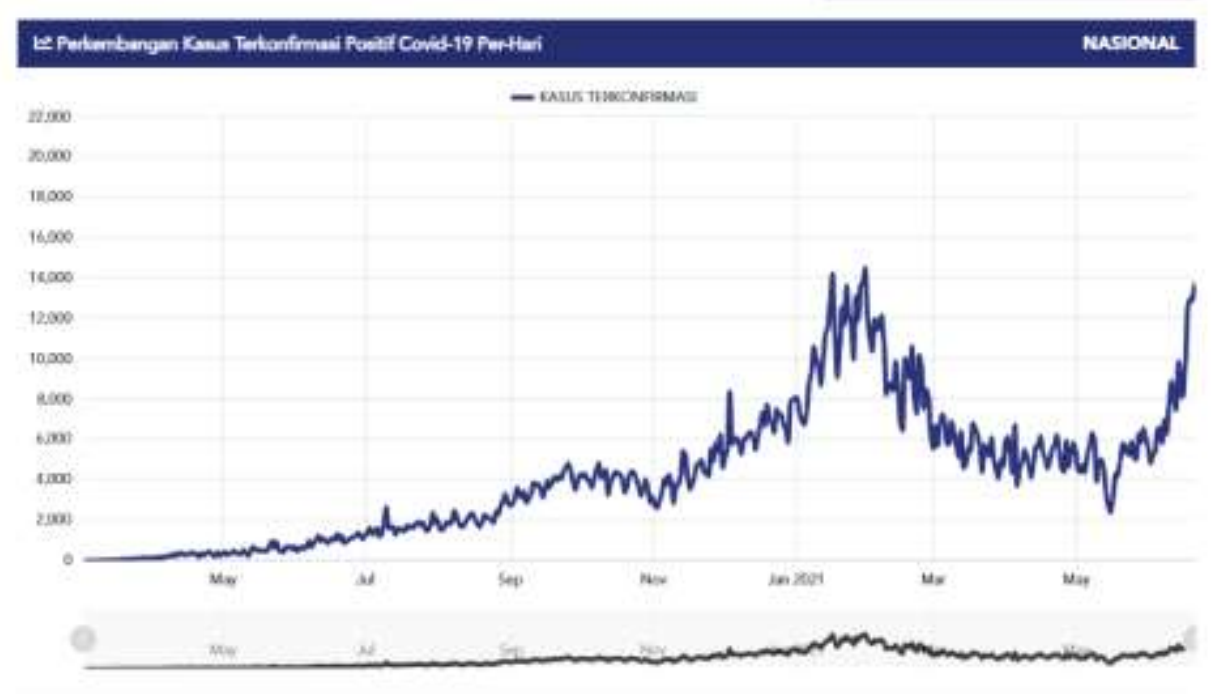

Table. 3

The Development of Positive Confirmed Cases of Covid In 2021

Source: https://covid19.go.id/peta-sebaran-covid19

The development of the growth of Covid-19 in Indonesia for one year from May 2020 to May 2021, the growth was very significant, peaking in May 2021 where the increase in positive Covid-19 averaged 14 thousand people. This condition is certainly very disturbing and has an impact on the availability of COVID-19 referral hospitals whose occupancy rates are above $75 \%$ outside the threshold set by WHO. There are even some hospitals in city and district areas whose occupancy rates are already full and even they do not accept those who are positive for COVID-19, of course, if this continues and the rate of decline is low, it will lead to limited medical personnel needs so that the handling of COVID-19 patients will not be optimal. which in turn will increase the death ratio of Covid-19 cases in Indonesia.

\section{Development of Covid-19 Cured Cases in 2021}

In general, during these 2 years, the positive growth of COVID-19 has increased in the third week of June, reaching 2 million people, with a recovery rate ratio of $90 \%$. The rate of cure ratio has a high 
percentage and needs to be maintained so that improvements in health infrastructure must be increased in order to increase the ratio of positive COVID-19 cures. The increase in the recovery ratio does not correlate with the decrease in the death ratio, it actually increases to $2.7 \%$, where Indonesia is currently one of the countries experiencing the highest mortality ratio in the world. This increase in the recovery ratio is due to the massive Covid-19 tests carried out by the government so that there is early prevention in the healing process. The high Covid-19 death ratio in Indonesia is due to the majority being of vulnerable age, in this case the elderly, whose mortality percentage is quite high in terms of age.

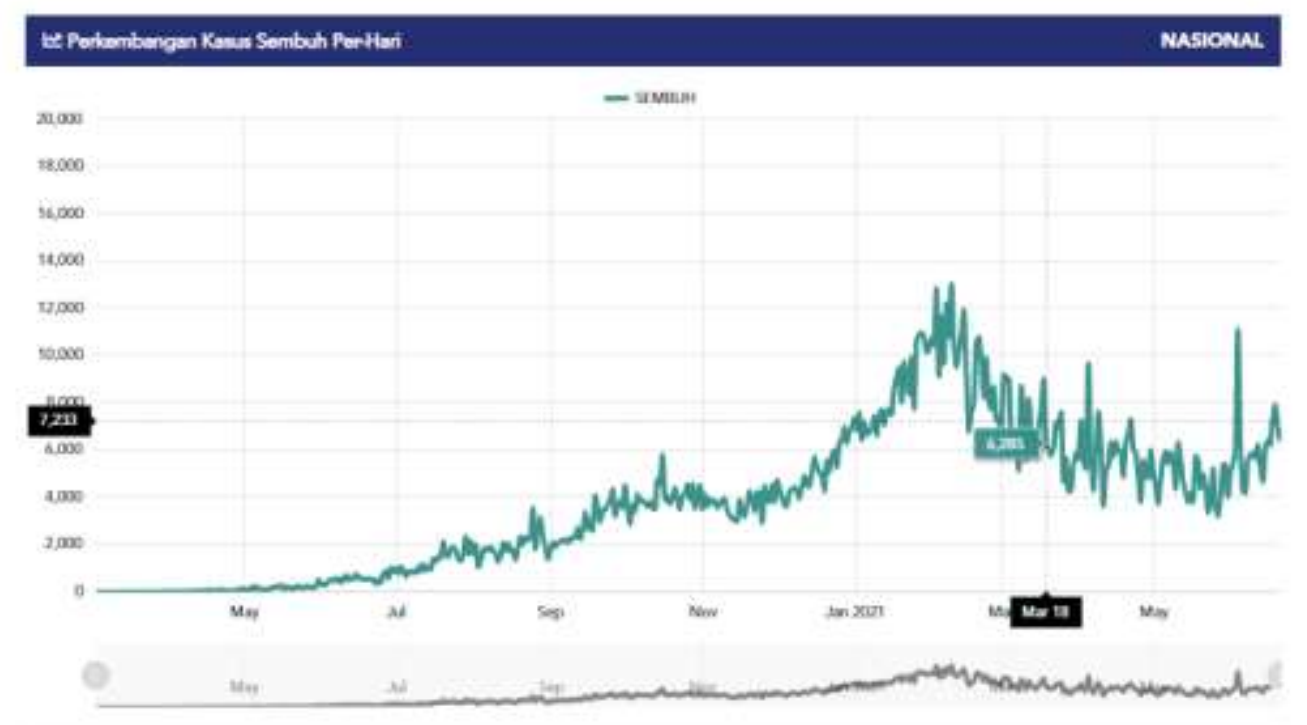

Table. 4

Progress of Healed Cases In 2021

Source: https://covid19.go.id/peta-sebaran-covid19

The cure ratio that occurred during 2020 to June 2021 does not correlate with a decrease in the positive covid19 but the increase in the recovery ratio is followed by an increase in the positive covid-19 ratio. As in March to June, the ratio of recovered patients was very high, on average 35004000 , but not comparable to the increase in those exposed to COVID-19. So if you look at the development from April 2020 to June the development of the healing rate is very high, the peak of the healing rate in February 2021 touched 13,000 people, it's just that from March to June the third week continued to decline while the positive number of covid-19 increased. So that the policies of the central and regional governments are very decisive in the development of the growth of COVID19. The biggest hope is the covid-19 vaccination that has been carried out by the government with the aim of being able to break the chain of the spread of COVID-19. it's just that its development has not shown significant results, this is due to the low ratio that has been vaccinated from the government's target of $\mathbf{1 8 0 . 5}$ million people, especially when compared to the total population of Indonesia.

\section{Development of Death Cases Due to Covid-19 Indonesia in 2020 - 2021}

The death rate ratio in Indonesia due to Covid-19 is very high, even one of the highest in the world, especially when compared to countries in Southeast Asia, East Asia and South Asia. Of course, this is very scary if it continues, the vast area, limited health personnel and limited supporting infrastructure make it an obstacle in the process of dealing with Covid-19. In June, the third week 
of 2021 became the highest peak for the last 2 years, the number of positive COVID-19 reached an average of 14,000 people per day. Followed by a high mortality rate. The high number of positive COVID-19 cases has reduced the cure rate. The increase in the positive growth of COVID-19 creates very complex problems and requires the right policies because if they are wrong, it will lead to an even bigger disaster.

The limited capacity of the hospital is a problem, which is now approaching $80 \%$ so that if by the end of June it is not possible to reduce the positive Covid-19 by breaking the spread rate, it will result in not being able to control patients exposed to COVID-19. Of course, this will be a new and scary problem because it will result in an increase in the death ratio due to COVID-19. Government policies are still on a macro scale whose implementation in the field has not been maximized so that the government's target so far has not been achieved in breaking the chain of distribution.

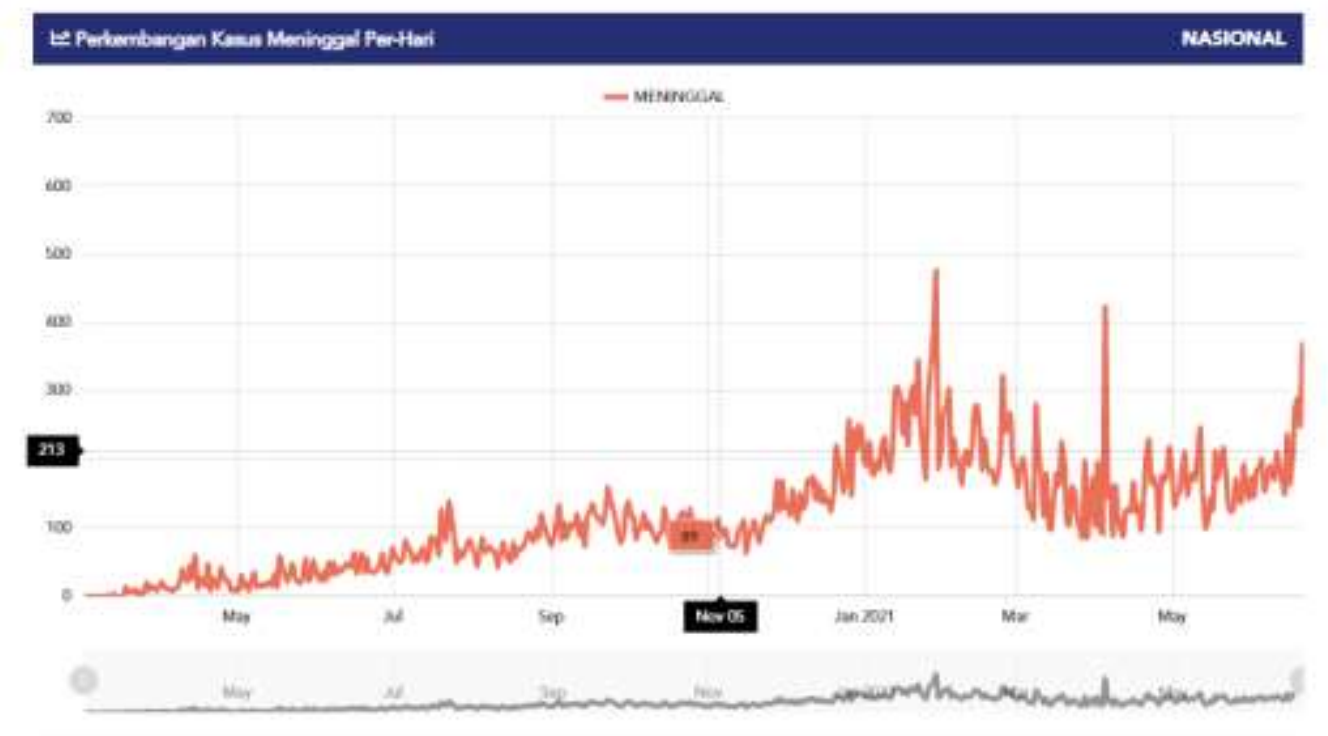

Table. 5

Death Case Progress In 2021

Source: https://covid19.go.id/peta-sebaran-covid19

The social barrier for 6 months is still on a micro scale at the City and Regency level, not yet on a national scale, this is due to government policies that want the community's economy to continue running and the current budget constraints, if a national lockdown is carried out, it is certain that the state will not be able to afford it bear the cost of living for the community, especially the lower middle class who have been hit hard by this Covid-19 pandemic.

Vaccination that has been running so far is still on a limited scale and is still far from the government's target of 180.5 million people, currently only less than $20 \%$ of its achievement. This positive increase in Covid-19 is a time bomb due to the lack of firmness of the apparatus in implementing the Health protocol and the lack of public awareness in maintaining health by implementing the Health protocol. The highest death rate was in February then fell in March and rose again in May and June 2021.

\section{Development of National Covid-19 Cases Per Day in 2021}

The development of covid- in Indonesia in general is still high, even the movement is one of the highest in Southeast Asia and East Asia, even in May and June 2021, the increase is very drastic, 
followed by a high death rate. The policies that have been carried out so far have not been able to break the chain of the spread of COVID-19 in Indonesia. The policy that does not carry out a national lockdown using only micro-scale social restrictions has resulted in the continued increase in the number of Covid-19 positives in the market again with a lack of awareness, the public in obeying the Health protocol rules that have been set by the government, the indecisive sanctions given are the cause for almost 2 years. this year the growth of covid-19 is increasing daily in the third week of June 2021, positive covid reaches 2 million people with an average daily in June of 14.6 thousand people. The government's policy that so far has kept the economy running is indeed on the one hand the purchasing power of the people has not decreased and the people still have the purchasing power to fulfill their lives. If you do a lockdown because the government's budget is limited so it's certain you won't be able to bear it

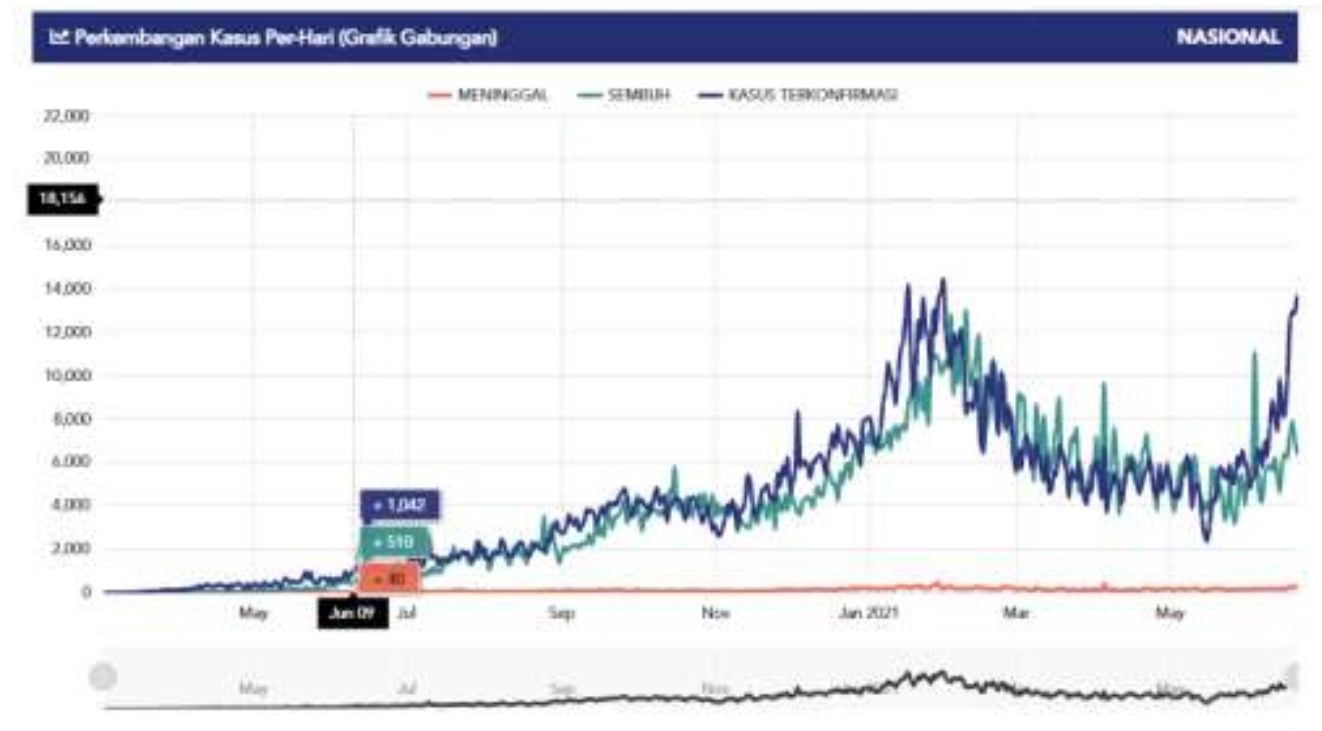

Table.6

Case Progress per Day In 2021

Source: https://covid19.go.id/peta-sebaran-covid19

Covid-19 growth, its growth from September 2020 continued to rise and peaked in February and March then gradually decreased, it's just that in April to May it experienced a progressive increase and peaked in June the positive increase in Covid-19 was not controlled, if this is allowed it will become a very frightening human disaster. One of the ongoing programs that the government has accelerated is mass vaccination, but until June 2021 the vaccination is only $20 \%$ less than the government's target of 180.5 million people. When compared to the population, the ratio is even smaller. We hope that this vaccination will be successful in accordance with the government's target because it can break the chain of spread of COVID-19 in Indonesia. The most serious obstacle faced is the availability of vaccines which still depend on foreign products with limited volumes. The national vaccine is currently still in the clinical trial stage and cannot be used, then there is still low public awareness and even those who refuse to be vaccinated for various reasons that make positive for Covid-19 so far has not shown any signs of decline.

\section{The Development of Positive Sex Covid-19 in 2021}


The positive number of Covid-19 in Indonesia during April to June continued to increase and the most dangerous people who were exposed to Covid-19 were children. Where out of 10 who are positive for COVID-19, one is a child, so this problem must be handled as soon as possible because otherwise the children will cause a humanitarian disaster. This is because the current recipients of the vaccine are only those who are 17 years of age and over, while there is no government policy that allows them below. Children are very vulnerable to the spread of COVID-19 where they need serious parental supervision in carrying out their social activities.

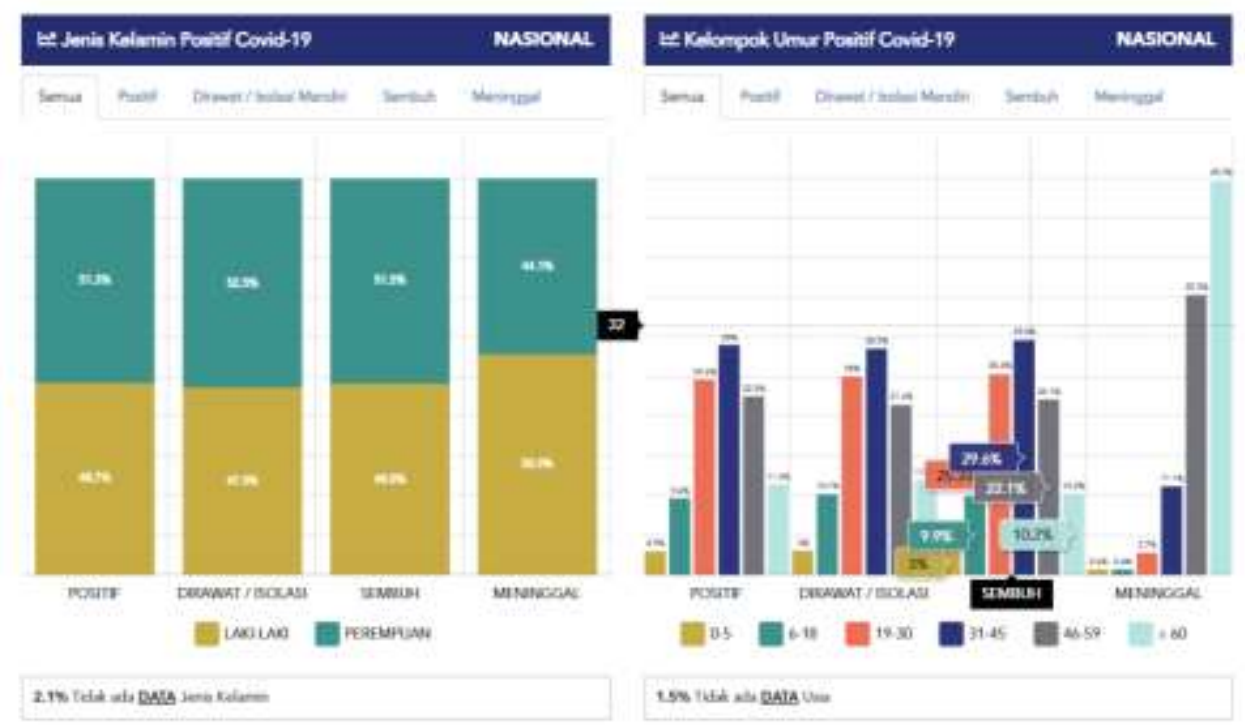

Table. 7

The Development of Positive Sex Covid-19 In 2021

Source: https://covid19.go.id/peta-sebaran-covid19

The case of the spread of Covid-19 in Indonesia during 2020 to June 2021 has exceeded 2 million people with a death rate of $2.7 \%$ which is a very high number even as one of the countries that has the highest death rate in the world. The percentage of COVID-19 cases based on gender is almost equal between men and women. Positive cases of Covid-19 were $51.3 \%$ for men, $48.7 \%$ for women, $52.5 \%$ for recovered patients and $48.5 \%$ for women and $44.1 \%$ for men and $45.9 \%$ for women who died.

\section{Development of Positive Symptoms of Covid-19 June 2021}

The development of covid-19 in Indonesia from March 2020 to June 2021, there are no signs of a decline in positive cases of covid-19 and even tends to increase, in June the third week the number of positive cases has touched 2 million people with an average number per day in the month of June. June 202114 thousand people. This situation has a tremendous impact on all aspects of people's lives from economic to social. The people's purchasing power has decreased, even the lower middle class is very difficult to survive so that the poverty rate soars high. Many factories were closed because there was no production due to decreased demand from the market as a result of mass layoffs everywhere which resulted in high unemployment rates. Of course, this problem adds to the burden on the government, which has been fighting hard to survive the COVID-19 outbreak. 


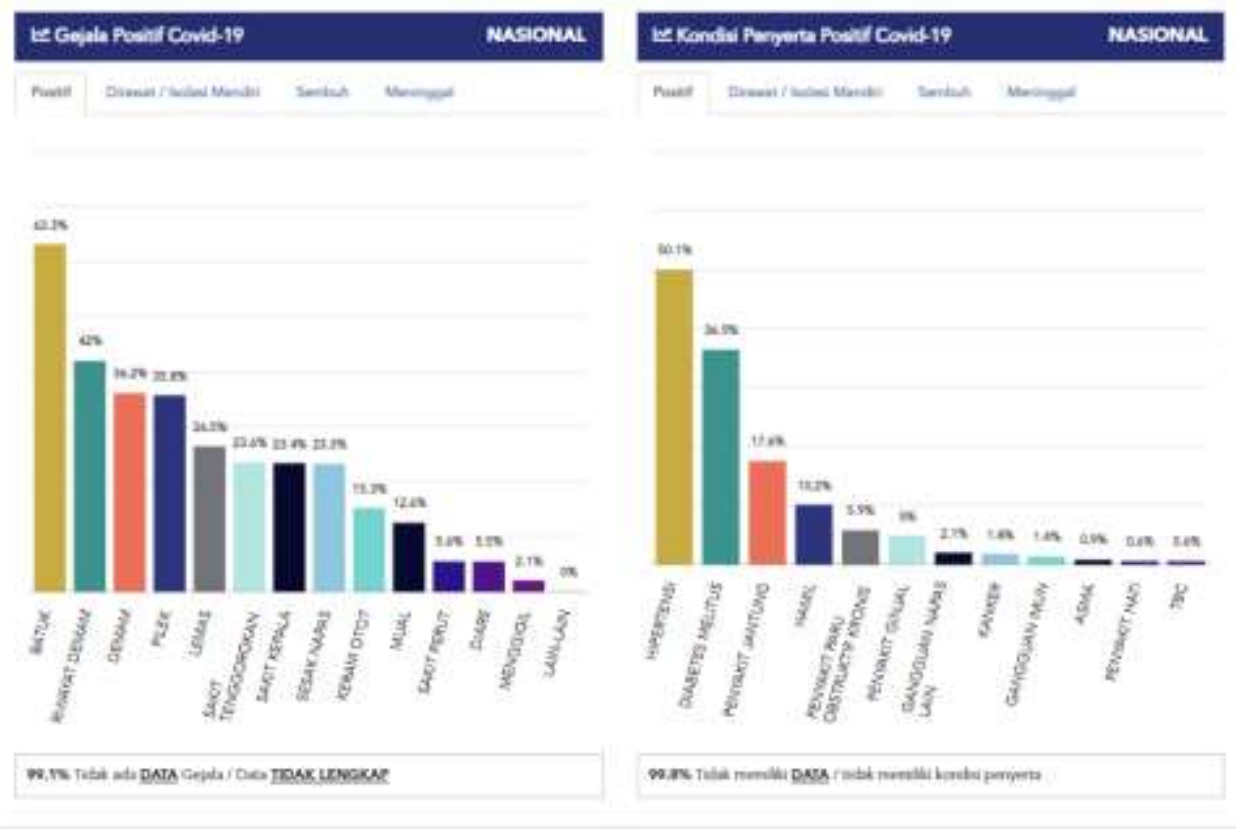

Table. 8

Development of Positive Symptoms of Covid-19 In 2021

Source: https://covid19.go.id/peta-sebaran-covid19

The high number of Covid-19 during May-June 2021, of course, one of the causes is the still opening of economic activities which result in direct community interaction, such as traditional markets, shopping centers, airports, ports and so on, then the public's awareness is still low in complying with the rules. the government that has been set, the apparatus is less strict in enforcing the law and seems selective and the last one is the small ratio of vaccinations that have been programmed by the government until June 2021, the achievement is less than $20 \%$ of the government's target of 180.5 million people who will be vaccinated. The general symptoms felt by patients exposed to COVID-19 were mostly cough $63.3 \%$, fever $36.2 \%$, colds $35.8 \%$, weakness $26.5 \%$, sore throat $23.6 \%$, headache $23.4 \%$, shortness of breath $23.3 \%$, muscle cramps $15.3 \%$, nausea $12.6 \%$, abdominal pain $5.6 \%$, diarrhea $5.5 \%$, chills $2.1 \%$. but there are some cases found that are positive for covid do not have any symptoms and the cases are increasing with asymptomatic covid-19 patients.

\section{The development of the condition of positive Covid-19 participants in 2021}

The development of the positive number of Covid-19 in Indonesia is increasing from March 2020 to June the third week of 2021. More than 2 million people have been positive for COVID-19 with the highest death ratio in the world at $2.7 \%$. The high positive number of covid is very many variables that influence it, starting from government policies that seem to float, namely social restrictions are only on a micro scale, economic activity is allowed to run with the hope that people still have purchasing power so that economic growth is maintained as targeted by the government. Then the loosening of mobility rules between countries where the government opens international flight routes and international ports so that the activities of citizens from abroad are still many who come in and out, the rules are not firm in enforcing the rules regarding the Health protocol with many violations of the Health protocol. the sanctions are still administrative in nature, not yet on criminal sanctions. And the most crucial thing is that the public is still not aware of implementing the Health 
protocol in maintaining their safety. This has resulted in the high number of Covid-19 positives in Indonesia.

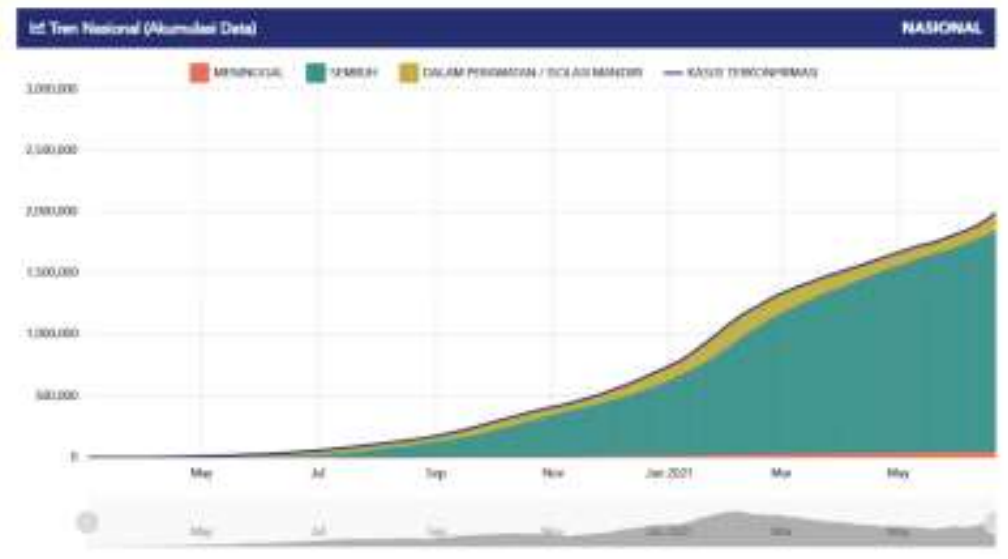

Table. 9

The development of the condition of the Covid-19 positive participant In 2021 Source: https://covid19.go.id/peta-sebaran-covid19

The development of covid-19 in Indonesia based on accompanying conditions for 12 months from May 2020 to May 2021 its development experienced the highest increase in growth from March to June 2021 where the increase in covid-19 per day averaged 10 thousand people and peaked in June the average per day is 14 thousand people. Positive society based on gender between men and women with a probability of $52 \%$ being male and $48 \%$ being female with comorbidities such as Cough, Cold, Dizziness and Shortness of breath and so on. In June 2021 the number of children who were positive for COVID-19 rose to a ratio of one in 10 who tested positive for Covid-19. This condition makes the government overwhelmed in the midst of a shortage of medical personnel and limited health facilities so that the average hospital occupancy rate is above $75 \%$, having exceeded the threshold set by the United Nations.

\section{Development of the National Trend of COVID-19 in 2021}

The trend of positive development of COVID-19 in Indonesia nationally from 34 provinces, almost all provinces handle positive cases of Covid-19 with an increasing trend. The provinces with the highest cases in Indonesia are dominated by Java, which consists of DKI Jakarta, West Java, Central Java, Jogjakarta and East Java. While the rest have small cases compared to the 4 provinces, one of the factors that causes this is having a large population, a province that is relatively more developed and is a production base for the homeland market. Jakarta as the State Capital as the center of government and also a business center is a province that has the highest positive number of Covid19 nationally, this is due to the high population, also due to the high mobility of people in the country's capital city.

Most of the workers in Jakarta are from satellite cities in West Java who use land transportation every day at work, so the policy that opens land transportation without being followed by strict Health protocol rules has resulted in a very high spread of COVID-19 in Jakarta. The limitations of the apparatus in enforcing rules and the lack of public awareness of using the Health protocol have also influenced the surge in COVID-19 in Jakarta in particular and in Indonesia in general. The patient 
occupancy rate in Jakarta has exceeded the predetermined already above 75 percent of the available capacity, if the government is not ready to handle this it will result in a greater humanitarian disaster.

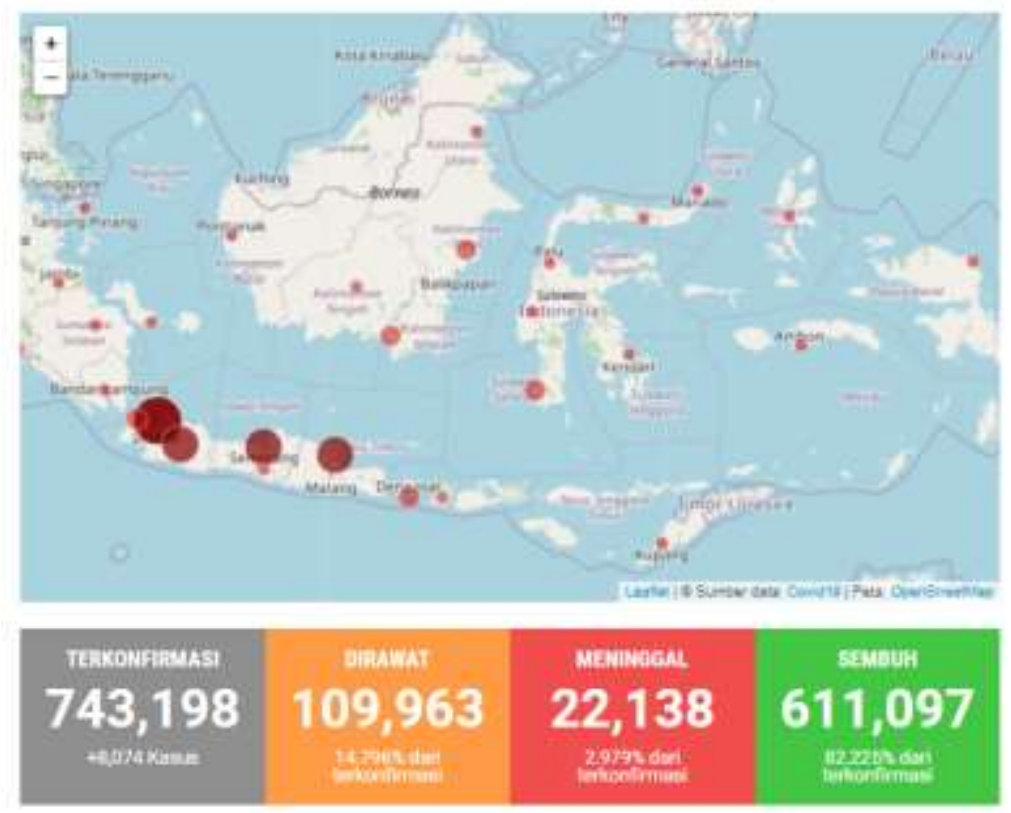

Tables. 10

Development of the National Trend of COVID-19 in 2021

Source: https://covid19.go.id/peta-sebaran-covid19

The cure ratio in Indonesia for Covid-19 patients is $90 \%$ with a death rate confirmed of $2.7 \%$ and in the third week of June, those who were positive for Covid-19 were over 2 million people with an average of 14,000 people per day. The national covid-19 program, which is one of the strategies in breaking the chain of national spread, has yet to show any sign of a significant impact, this is due to the low level of new vaccinations below $20 \%$ of the government's target of 180.5 million people, the limited vaccine is available because it is still depends on vaccines from abroad, namely from China, Europe and America which incidentally they also need. Uneven distribution channels due to the large area handled with different infrastructure conditions, these factors greatly affect the still high positive number of Covid-19 in Indonesia. The national vaccine that has been developed at this time is still at the clinical trial stage and has not been used, which is a big hope for breaking the chain of Covid-19 spread in Indonesia.

\section{Distribution Map of Foreigners by Province June 2021}

Government policies that continue to open community economic activities, open flights, ports and international transportation have a high correlation with the spread of COVID-19 in the country. Even though Asian countries have closed international flights, Indonesia is still opening for economic reasons to keep it running. So that the Covid-19 rate for foreign nationals is very high, either exposed in their country and resulting in transmission in the country or exposed while in the country. 


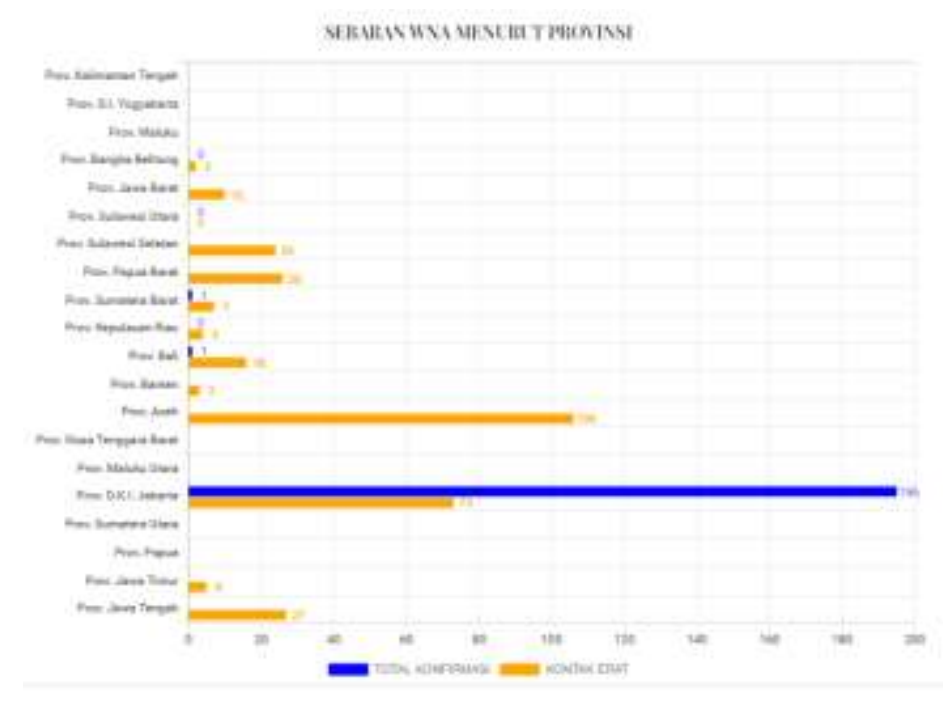

Table.11

Distribution Map of Foreigners by Province In 2021

Source: https://covid19.go.id/peta-sebaran-covid19

The highest cases of COVID-19 spread are still in the province of DKI Jakarta, as the nation's capital, which has a positive number of Covid-19 for foreign nationals, the second is that the province of Aceh, both of these regions, have a high rate of Covid-19 cases against foreigners. The spread of COVID-19 cases is through close contact, starting from socialization, business, tourism and so on. There were even some cases of planes from abroad, especially from East Asia, when tested when they arrived, many were positive for Covid, which made the situation even worse when they were waterproof. So that evaluating international transportation, it is necessary to carry out technological limitations in screening and the wide area that must be covered is a gap for foreign countries who are positive for COVID-19 entering the country. Then the number of Indonesian workers who work abroad such as the Middle East, East Asia and Southeast Asia has a strong correlation to the spread of COVID-19 in the country.

\section{COVID-19 Risk Zoning Distribution Map}

The map of the distribution of Covid-19 in Indonesia in general is almost evenly distributed, from 34 provinces there are only a few until June 2021, there have been no positive cases of Covid-19, while the rest there have been cases of Covid-19. The highest spread of COVID-19 is on the island of Java, which consists of DKI Jakarta, West Java, Central Java, Yogyakarta and East Java. Nationally, DKI Jakarta is the highest positive case of Covid-19 in Indonesia. 


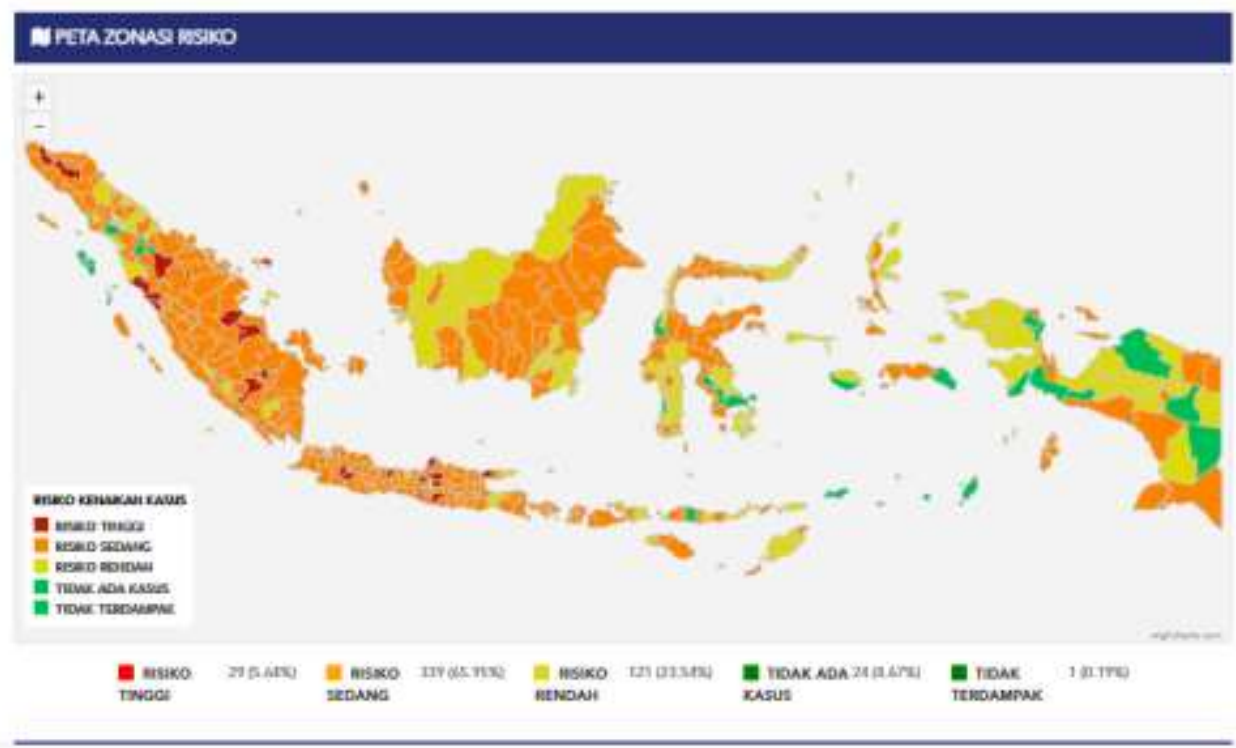

Table.12

Map of Distribution of COVID-19 Risk Zoning In 2021

Source: https://covid19.go.id/peta-sebaran-covid19

In general, the spread of COVID-19 is in big cities that have a very high population density and heterogeneity with high community mobility, such as Jakarta as the nation's capital, being the center of government, business center, financial center. With its high city mobility having a correlation to the spread of COVID-19, then West Java is one of the provinces that has the largest population in Indonesia apart from being a satellite province that supports the capital city, it is also a province that has a very high number of tourist destinations, so that until now it has become one of the largest cities in Indonesia. one of the largest positive numbers for COVID-19, followed by Central Java, East Java and Yogyakarta.

\section{National Covid-19 Vaccination Development}

The Covid-19 vaccination is an absolute must for all Indonesian people so that the Covid-19 case is immediately completed. This becomes very decisive in preventing and reducing the spread of positive cases. So far, the vaccinations that have been running have only been carried out by only a few segments/groups of society such as civil servants, TNI and Polri as well as teachers and lecturers as well as for the elderly. The limited number of vaccines is an obstacle in accelerating national vaccination so that the number of vaccinations is very decisive in the success of vaccination. Socialization and education to the public is very important in the success of this vaccination, this is because there are still many people who are not willing to be vaccinated so that it will interfere with the success of this covid-19 vaccination.

The acceleration of the use of national vaccines, which is currently still in clinical trials, is a decisive instrument in meeting the needs of vaccines in the country so that organization and delegation of tasks and responsibilities in the national covid-19 vaccine program is needed. Strict and clear rules must still be implemented strictly and responsibly for taking advantage of the situation for individual or group interests, which will harm the national interest. 
Quantitatively, the ratio of vaccinations in Indonesia is still small compared to the target set by the government of 181.5 million, especially compared to Indonesia's population of 297 million. As of June 22,2018 , the number who had received the vaccine was 23.7 million and those who received the second vaccine were 12.5 million. This small ratio is caused by various things, such as the number of vaccines available, which still depend on foreign countries, which in fact they currently need, so in other words, it is very difficult to get vaccines according to needs such as from China, America and Europe. Then the vaccine distribution is not yet fast, this is due to the large area with limited infrastructure so that there are still many areas that have not been able to carry out vaccination in the sub-district or village so that the distribution channel is a determinant of the success of this vaccination.

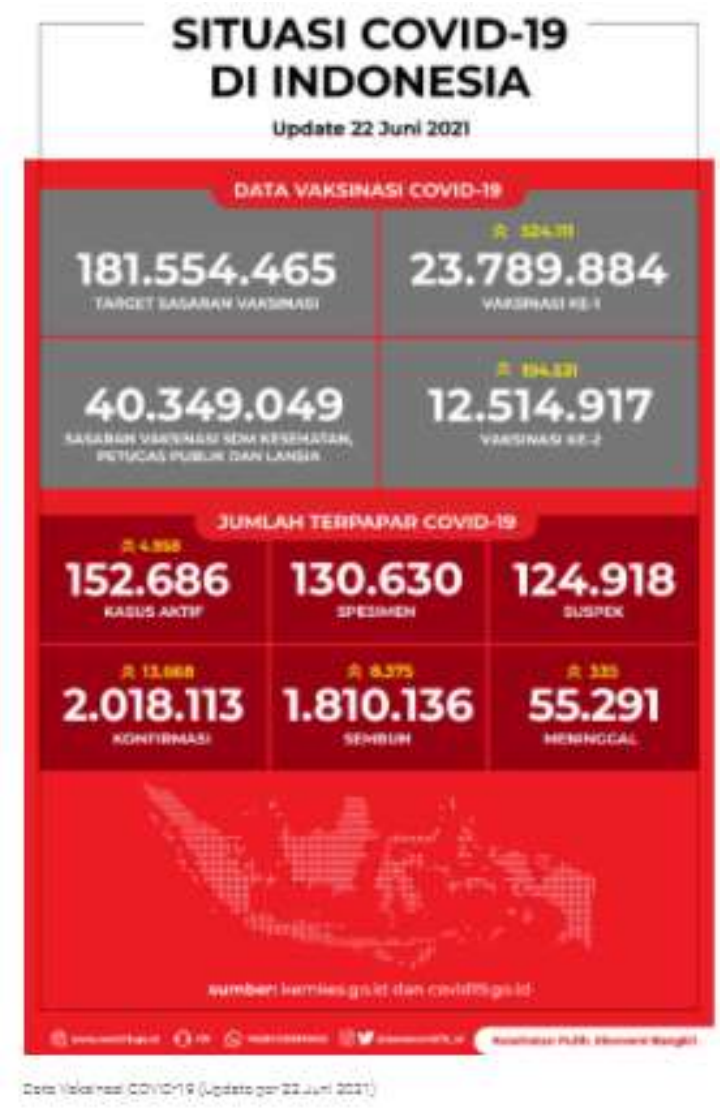

Table. 13

Distribution of COVID-19 Vaccination In 2021

Source: https://covid19.go.id/berita/patient-sembuh-terus-meningkat-menunjuk-1810136-orang

Nationally, the number of people who were positive for COVID-19 rose dramatically during April, not positively correlated with the increase in the number of people who had received the vaccine. So that the increase in the ratio of the population to vaccination must be high so that it can reduce the positive number of covid-19. The death rate ratio is a warning to the government because Indonesia currently has a high mortality ratio for COVID-19, which is $2.7 \%$ of those who are positive for Covid or 55,000 who have died. And those who are positive for COVID-19 have touched 2 million people with a positive recovery rate of 1.81 million people.

Quantitatively, the Covid-19 recovery ratio is quite high, more than $80 \%$, but looking at the indicators or ratio of vaccines with a small population, if this is not solved seriously, it will become 
a time bomb for the government, namely the Covid-19 growth explosion. Of course, this will be a national disaster and will worsen the current situation due to COVID-19. so that vaccinations to the community must be carried out en masse by using the resources owned by the state optimally because if this is allowed it will result in greater losses.

\section{The Development of the Covid-19 Situation}

The government has decided to tighten community activities as an effort to control COVID-19 cases, the trend of which continues to increase after the Eid holiday. This step is stated in the Instruction of the Minister of Home Affairs No. 14 of 2021. The tightening is divided based on risk zoning at the district/city level. District/city zoning is dynamic so that it is the obligation of the Regional Government to periodically monitor the movement (trend) of this zoning, the Regional Government must be more sensitive in reading zoning trend data in its territory. If more than a week the zoning still remains in the orange or red zone, then handling efforts such as Micro PPKM must be evaluated. Furthermore, this effort is also expected to be able to train regional capabilities to carry out good gas-brake efforts based on their high sensitivity to the conditions of COVID-19 cases. Not only that, the government must continue to motivate the optimization of Micro PPKM and the function of the Command Post. In principle, when a district/city is instructed by the provincial government to run a district/municipality PPKM, automatically all villages/kelurahan under it will run a Micro PPKM.

\begin{tabular}{|c|c|c|c|c|c|c|}
\hline \multirow[b]{2}{*}{ ZONASI } & \multicolumn{6}{|c|}{ AKTIFITAS } \\
\hline & Perkantoran & Belajat Mengajar & Kegiatan lbadah & $\begin{array}{l}\text { Papat, Seminat, } \\
\text { Pertemua Luring }\end{array}$ & $\begin{array}{l}\text { Keqiatan Seni. } \\
\text { Budaya \& Sosial }\end{array}$ & Area Publik \\
\hline & $\begin{array}{l}\text { WFH } 75 \% \\
\text { WFO } 25 \%\end{array}$ & $\begin{array}{c}\text { Daring } \\
\text { (Jarak Jâh) }\end{array}$ & $\begin{array}{l}\text { Ditiadakan } \\
\text { Sementara }\end{array}$ & $\begin{array}{c}\text { Ditutup } \\
\text { Sementara }\end{array}$ & $\begin{array}{l}\text { Ditutup } \\
\text { Sementara }\end{array}$ & $\begin{array}{l}\text { Ditutup } \\
\text { Sementara }\end{array}$ \\
\hline & $\begin{array}{l}\text { WFH } 50 \% \\
\text { WFO } 50 \%\end{array}$ & $\begin{array}{l}\text { Tatap Muka } 8 \\
\text { Jarek Jauh }\end{array}$ & $\begin{array}{l}\text { Ditiadakan } \\
\text { Sementara }\end{array}$ & $\begin{array}{l}\text { Dibuka dengan } \\
\text { Kapasitas 25\% }\end{array}$ & $\begin{array}{l}\text { Dibuka dengan } \\
\text { Kapasitas } 25 \%\end{array}$ & $\begin{array}{l}\text { Dibuka dengan } \\
\text { Kapasitas } 25 \%\end{array}$ \\
\hline & $\begin{array}{l}\text { WFH } 508 \\
\text { WFO } 508\end{array}$ & $\begin{array}{c}\text { Tatap Muka } 8 \text {. } \\
\text { Jarak Jauh }\end{array}$ & $\begin{array}{l}\text { Dibuka } \\
\text { Terkendali }\end{array}$ & $\begin{array}{l}\text { Dibuka dengan } \\
\text { Kapasitas } 25 \%\end{array}$ & $\begin{array}{l}\text { Dibuka dengan } \\
\text { Kapasitas } 25 \%\end{array}$ & $\begin{array}{l}\text { Dibuka dengan } \\
\text { Kapasitas } 25 \%\end{array}$ \\
\hline & $\begin{array}{l}\text { WFH Sos } \\
\text { WFO } 504\end{array}$ & $\begin{array}{c}\text { Tatap Muka \& } \\
\text { Jarak Jauh }\end{array}$ & $\begin{array}{l}\text { Dibuka } \\
\text { Terkendali }\end{array}$ & $\begin{array}{l}\text { Dibuka dengan } \\
\text { Kapasitas } 25 \%\end{array}$ & $\begin{array}{l}\text { Dibuka dengan } \\
\text { Kapasitas } 25 \%\end{array}$ & $\begin{array}{l}\text { Dibuka dengan } \\
\text { Kapasitas } 25 \text { \$ }\end{array}$ \\
\hline
\end{tabular}

Table. 14

The Development of the Covid-19 Situation In 2021

Source: https://covid19.go.id/berita/kepekaan-membaca-situasi-key-controlling

District/City PPKM and Micro PPKM are both control efforts. What makes the difference is that the District/City PPKM aims to monitor large sectors such as restaurants, shopping centers, offices, and other sectors, including monitoring the implementation of Micro PPKM. Meanwhile, PPKM Micro has a specific function to supervise activities in the community which are generally difficult to control. In addition, the government is also maximizing the prevention of a spike in cases. This stipulation is not intended to violate workers' rights, but merely as a form of anticipating the possibility of a spike in cases after a long holiday period.

Complementing all these control efforts, the government also continues to make efforts to increase vaccinations. The fulfillment of vaccination needs continues to be carried out, the latest is that on June 20, 2021, Indonesia again received bulk vaccines (raw materials) from Sinovac, which was the 
17th arrival of COVID-19, with a total of 10 million doses. This shows that transmission still exists and vaccines do not fully protect against transmission, individual immunity is not sufficient to reduce transmission and to overcome it requires community immunity (herd immunity). The arrival of this vaccine is the government's effort to accelerate the achievement of herd immunity so that it is hoped that the community can participate in the vaccination program and also remain disciplined in complying with health protocols so as to minimize transmission that can occur.

\section{Optimization of PPKM COVID-19 Optimization}

Local governments must optimize district/city PPKM as well as Micro PPKM now. This is inseparable from the development of the COVID-19 pandemic that occurred in the last four weeks which showed six provinces on the island of Java as the highest contributor to the increase in cases in Indonesia. Regional leaders at the provincial and district/city levels, especially in Java, must be accustomed to observing the current situation by reading good data so that anticipatory steps can be taken immediately. Use the data as the basis for policy making in handling COVID-19 so that the resulting policies can be targeted and able to control the spike in cases. Based on data as of June 20, 2021, the six provinces in Java that contributed to the highest increase in cases were: DKI Jakarta increased by $387 \%$, with a total increase of 20,634 cases; West Java increased by $115 \%$, with a total increase of 8,382 cases; Central Java increased by $105 \%$, with a total increase of 5,896 cases; East Java increased $174 \%$ with a total increase of 2,852 cases; DI Yogyakarta increased by $197 \%$, with a total of 2,583 cases; and Banten increased by $189 \%$, for a total of 967 cases.

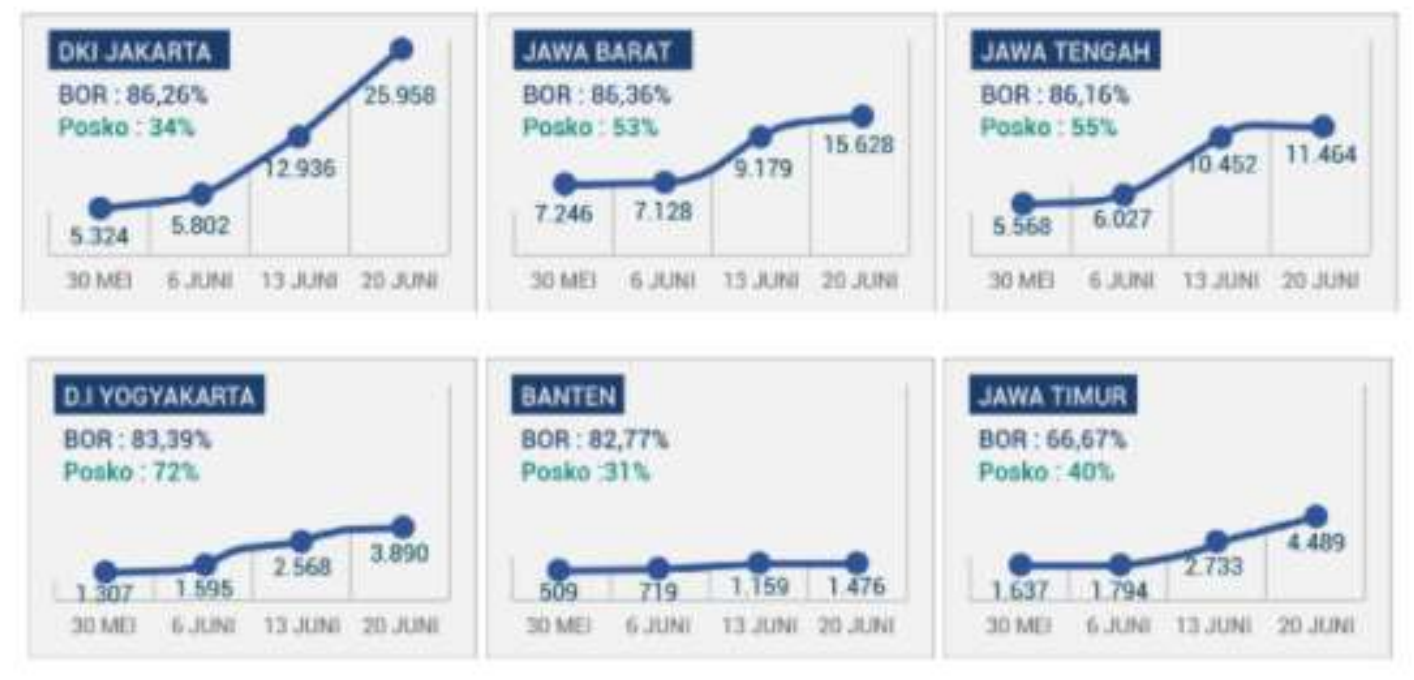

Table. 15

Graph of Optimization of PPKM COVID-19 In 2021

Source: https://covid19.go.id/berita/satgas-minta-region-optimalisasi-ppkm-now-juga

These developments have made Indonesia nationally experienced an increase in weekly cases of $92 \%$ since the last 4 weeks. "This is a very sharp rise, and it cannot be tolerated. This increase was also followed by an increase in the BOR or bed occupancy rate in the isolation room of the Covid referral hospital. In fact, the BOR for 5 of these 6 provinces reached more than $80 \%$ as of June 21, 2021. Only East Java Province had a BOR below $80 \%$, which is $66.67 \%$. This increase in positive cases should be a strong reason for us to evaluate control policies together. To be able to ensure the 
effectiveness, especially the implementation of the Micro PPKM policy, all elements must carry out their duties and functions properly so as to create a comprehensive handling.

The percentage of Posko formation in various provinces in Indonesia still tends to be low and it is important to remember, the effectiveness of the implementation of Micro PPKM is very dependent on the formation of Posko as a forum for coordinating the implementation of Micro PPKM at the Village/Kelurahan level. There are still many villages/kelurahan that do not yet have a command post, of course, it has the potential to cause obstacles to good coordination of handling COVID-19 to the RT level, so that it has an impact on not achieving the goals of the micro PPKM itself. Therefore, the Governors, especially from these 6 provinces, must immediately instruct the Regents and Mayors in their regions to improve the performance of Micro PPKM. If the post has been formed, the next step is to ensure that all the tasks and functions of the post are carried out properly by each of the related elements. Remember that COVID-19 is a race against time and the guarantee is life, so if all local governments can take anticipatory steps as early as possible, it can save many lives.

\section{The Ratio of Healing With Positive Covid-19}

Cases of COVID-19 transmission in Indonesia continue to increase, even reaching a record for the highest daily increase in cases during the pandemic on June 21 with 14,536. In addition, over the past five weeks, new cases have always been higher than the cure rate, with a peak difference of 17,391 cases this week. The condition of the high number of positive cases compared to the weekly cure rate needs attention. The lower cure rate compared to positive cases needs to be the main target for improving the handling of COVID-19. Furthermore, based on data as of June 20, 2021, there are six provinces that have the largest gap between positive cases and cure rates. These six provinces come from the island of Java, namely: DKI Jakarta (a difference of 13,032 cases); Central Java (difference 7,171 cases); West Java (a difference of 6,670 cases); East Java (difference 2,239 cases); DI Yogyakarta (2,131 cases difference); and Banten (878 cases difference).

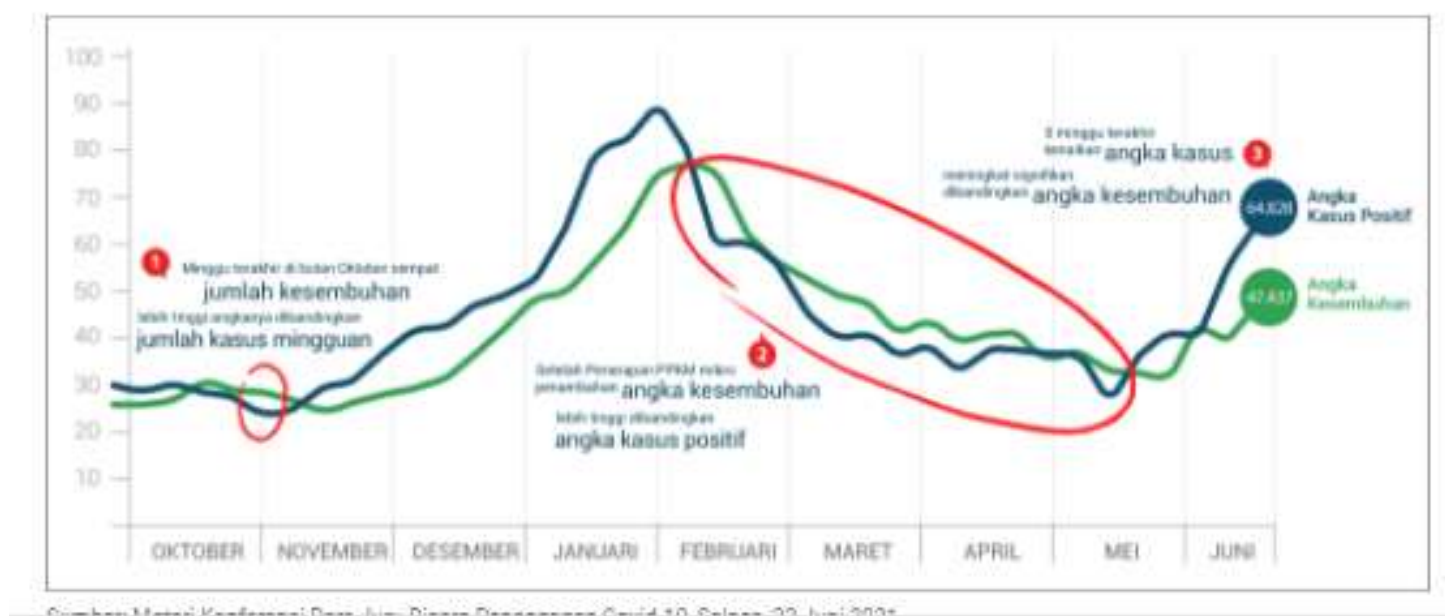

Table. 16

Graph of Healing Ratio With Positive Covid-19 In 2021

Source: https://covid19.go.id/berita/angka-kesembuhan-more-low-dari-case-baru-patut-jadi-fokushandling 
In addition to the high gap between positive cases and cure rates, the Task Force also highlighted six provinces with the highest active cases, namely: West Java (29,784 active cases); DKI Jakarta (11,411 active cases); Central Java (10,050 active cases); Papua (8,799 active cases); Riau (6,291 active cases); and the Riau Archipelago (3,431 active cases. All of these provinces must immediately improve the condition of COVID-19 in their regions through evaluation of policies implemented related to community activities. Adjust regulations regarding the capacity of offices, shopping centers, restaurants and places to eat, tourist attractions, and other public facilities Furthermore, the regional government is to improve the quality of handling COVID-19 patients in referral facilities. With the current high number of cases, and to implement recommendations from 5 medical professional organizations (Perdatin, PDPI, PAPDI, IDAI, and PERKI) that the strategy that must be done is to apply "early over treatment" where hospital patients who have experienced improvement in symptoms can be immediately referred to continue self-isolation at home, so that hospital capacity becomes larger and able to accommodate patients with moderate-severe symptoms. other.

In addition, hospital bed conversions can also be carried out, or provide centralized isolation facilities in each area so that the burden can be shared and the hospital is not overwhelmed in handling patients. If all of these provinces are able to reduce the addition of positive cases and increase recovery, it can boost the cure rate at the national level as well.

\section{Covid-19 Situation in Indonesia}

The current situation of the development of Covid-19 in Indonesia is very worrying, namely the growth rate of Covid-19 is very high, even the highest in Southeast Asia, many variables have resulted in the high spike in Covid-19, which on average during June 2021 was 9,000 positive Covid-19 people with The highest death ratio in the world is of course a warning that the government must be aware of. The factors that cause this high case are the euphoria of the community after being vaccinated, feeling immune so they do not heed the Health protocols, they forget that they have children who have not been vaccinated as a result, 1 in ten who are positive for COVID-19 are children.

The lack of firmness in government regulations regarding the handling of COVID-19 seems to have a dichotomy and even marginalization of policies between certain communities, certain groups and even between the community and officials so that crowds continue to occur, there are many violations of the Health protocol. As for the decisive action of the apparatus only temporally, it is not carried out continuously and continuously and there is a lack of good coordination in every line of agency that is closely related to COVID-19. Then the government policy that uses the two-legged policy, continues to move the wheels of the economy on the other hand limiting social activities of the community where the social restriction policy is carried out by the city, district and provincial levels. So that activities are not carried out nationally like other countries. Indeed, the government is in a dilemma in carrying out this policy, this is due to the limited budget it has so that if a lockdown is carried out how will the fate of the community meet their needs while the state is unable to bear it.

The factor that most greatly influenced the surge in COVID-19 was feeling tired, bored and bored with the situation, Covid-19 caused the economy to slump, poverty and unemployment increased. While the community must continue to survive to live, on the one hand the community realizes that Covid-19 is very dangerous but on the other hand they need provisions to maintain their lives so that people continue to carry out economic activities even though the risk of being exposed to COVID-19 is very large due to compulsion and pressure from economic needs. 


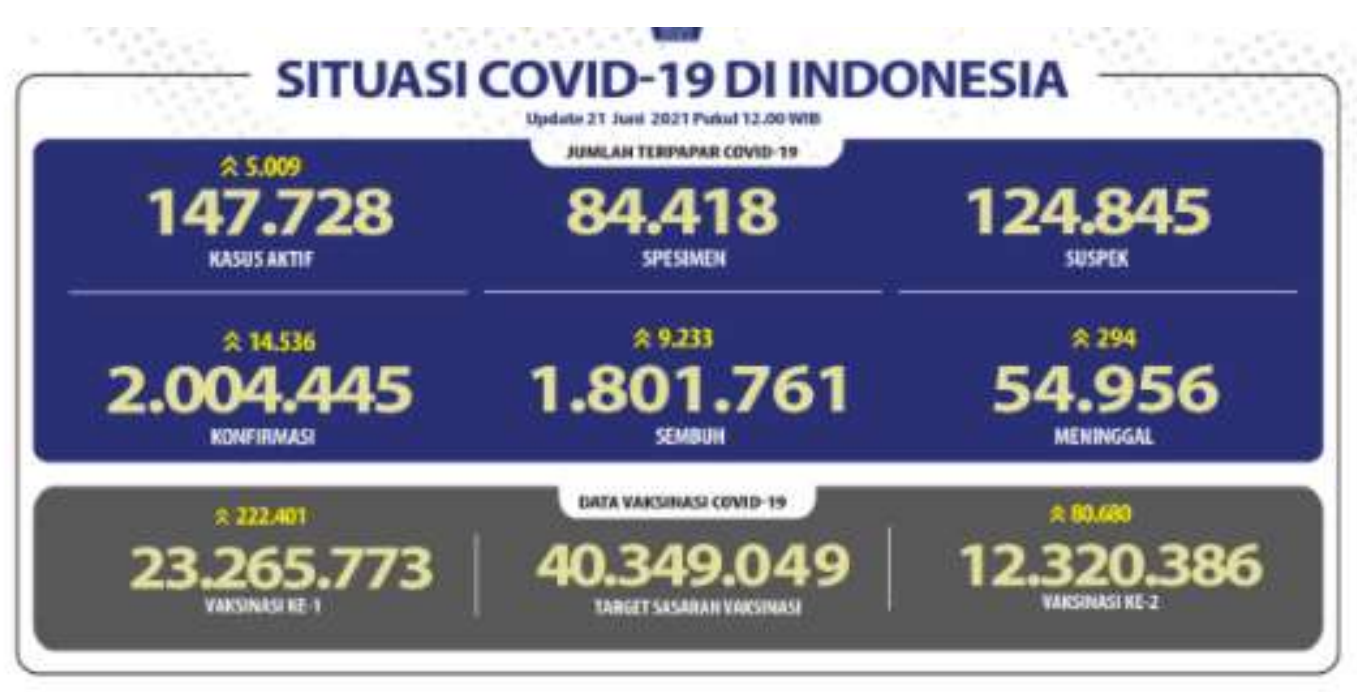

Tables. 17

Distribution of COVID-19 Healed Patients In 2021

Source: https://covid19.go.id/berita/patient-sembuh-bercepat-menembus-angka-18-juta-orang

As of June 21,2021 , the number of recovered patients has increased by 9,233 people. This cure rate adds the cumulative number of cures to more than 1.8 million people recovered, or the exact number increased to $1,801,761$ people with the percentage being $89.9 \%$. The number of active cases or patients who still need medical treatment increased by 5,009 cases and the total number was 147,728 cases with a percentage of $7.4 \%$. The finished specimens were examined by RT-PCR/TCM and 84,418 specimens per day rapid antigen test with a total of 124,845 suspected cases. In patients who were confirmed positive through the RT-PCR/TCM and rapid antigen examination methods, an increase of 14,536 cases. With the cumulative number, or positive confirmed patients recorded since the first case until today, it reached 2,004,445 cases. In patients who died increased by 294 cases and the cumulative reached 54,956 cases or the percentage was $2.7 \%$ of confirmed positive patients. Meanwhile, in the development of the COVID-19 vaccination program, the number of recipients increased to more than 23 million people, or to be exact, $23,265,773$ people. This increase was due to the addition of 222,401 daily vaccine recipients. Meanwhile, those who received the second vaccination increased to $12,320,386$ people. The target for vaccination is $40,349,049$ people.

Looking at the development of treatment per province, there are five provinces adding the highest daily recovered patients. DKI Jakarta Province added 2,385 people and cumulatively 438,739 people, Central Java added 2,207 people and cumulatively 193,457 people, West Java added 1,245 people and cumulatively 312,448 people, Riau added 405 people and cumulatively 63,118 people and Riau Islands added 401 people and a cumulative 18,816 people. Then, with the addition of daily positive confirmed cases, there were 5 provinces with the highest numbers. Namely DKI Jakarta added 5,014 cases and a cumulative 479,043 cases, Central Java added 3,252 cases and a cumulative 230,400 cases, West Java added 2,719 cases and a cumulative 347,287 cases, East Java added 719 cases and a cumulative 164,267 cases and DI Yogyakarta added 662 cases and a cumulative 53,303 cases .

In addition, there are 5 provinces with the highest daily death rates including DKI Jakarta adding 74 cases and a cumulative 7,842 cases, East Java adding 50 cases and cumulatively 12,044 cases, Central Java adding 38 cases and cumulatively 9,955 people, West Java adding 28 cases and a cumulative 4,637 cases and Lampung added 18 cases and the cumulative number was 1,082 cases. 
In addition, the results of tests per day from laboratory networks in various regions, the cumulative number of specimens examined has reached 18,734,036 specimens. Consists of 3,712,093 positive specimens and 13,350,841 negative specimens. The daily specimen positivity rate (NAA and Antigen) is $29.34 \%$ and the weekly specimen positivity rate (13 - 19 June 2021) is $27.57 \%$. Meanwhile, invalid and inconclusive specimens (per day) amounted to 259 specimens. For the number of people being examined per day, there are 62,361 people and the cumulative number is $12,533,392$ people. Then in the negative confirmed results, the cumulative number increased to $10,528,947$ people including today's addition of 47,825 people. Meanwhile, the daily person positivity rate is at $23.31 \%$ and the weekly person positivity rate (13-19 June 2021$)$ is at $17.33 \%$. And the distribution of regions is still in 34 provinces and 510 regencies/cities.

\section{BIBLIOGRAPHY}

Anung Ahadi Pradana, Casman, Nuraini. 2020. "Pengaruh Kebijakan Social Distancing pada Wabah Covid-19 Terhadap Kelompok Rentan di Indonesia".

Endang Naryono. 20219 "Sistematika penulisan skripsi program sarjana". Sukabumi : STIE PASIM SUKABUMI

Endang Naryono. 2020 "Strategi Pemasaran". Sukabumi : STIE PASIM SUKABUMI

Endang Naryono. 2019 "capitalizem in disater case studi of covid19". www.econpapers.org

Endang Naryono 2020 "Impact of national disater covid19, Indonesia toward economic recession". www.econpapers.org

Jurnal Kebijakan Kesehtan Indonesia (JKKI). Volume 09 Nomor - Juni Ahmad Fatoni. 2020. Dampak Covid-19 dan Kebijakan PSBB Pemerintah Terhadap UMKM di Wiyung Surabaya.

Jurnal Prodi Ekonomi Syari'ah. Volume 3 Nomor 1 - Februari Made Irma Lestari. 2020. “Signifikansi Pengaruh Sentimen Pemberlakuan PSBB Terhadap Aspek Ekonomi: Pengaruh Pada Nilai Tukar Rupiah dan Stock Return".

Jurnal Bina Akuntansi. Volume 07 Nomor 02 - Juli Alek Wissalam Bustami. 2020. "Pengaruh Covid19 Terhadap Perekonomian Masyarakat di Desa Pondok Kecamatan Bukit Kerman". Jurnal AlDzahab. Volume 1 Nomor 1 - Februari Silpa Hanoatubun. 2020. “Dampak Covid19 Terhadap Perekonomian Indonesia".

Jurnal of Education, Psychology and Counseling. Volume 2 Nomor 1 - Maret Lppm.unpam.ac.id (2020, 18 April). Pandemi Virus Corona (Pandemi COVID19) dan Dampaknya Terhadap Perekonomian.

Diakses pada 7 Agustus 2020 dari http://Ippm.unpam.ac.id/2020/04/18/pan demi-virus-coronapandemi-covid-19- dan-dampaknya-terhadapperekonomian/ Haluanindonesia.co.id (2020, 19 Mei). Kabupaten Pemalang Terapkan Jam Malam Mulai Minggu Depan.

Diakses pada tanggal 7 Agustus 2020, dari https://haluanindonesia.co.id/kabupate n-pemalangterapkan-jam-malammulai-minggu-depan/ Bank Indonesia, (2013).

Pengelolaan Keuangan. Jakarta: Grup Pengembangan Keuangan Inklusif Departemen Pengembangan Akses Keuangan dan UMKM Bank Indonesia.

Lestari, S. (2012). Psikologi Keluarga : Penanaman Nilai dan Penanganan Konflik dalam Keluarga. Jakarta: Kencana. Mulyanti, D., \& Sahidillah, N. (2018).

Pelatihan Perencanaan Keluarga bagi Ibu-ibu PKK Desa Cimenyan Kabupaten Bandung. Jurnal Abdimas BSI, 1 (2), 259-267. Ridwan, S., \& Inge, B. (2003). Manajemen Keuangan. Jakarta: Literata Lintas Media.

Siagian, S. P. (2008). Manajemen Sumber Daya Manusia. Jakarta: Bumi Aksara. Sukirman, H, R., S, D., \& P, A. (2019). Pengelolaan Keuangan Keluarga dalam Rangka Peningkatan Masyarakat Mandiri dan Berperan dalam Peningkatan Literasi Keuangan Indonesia (Otoritas Jasa 
keuangan). Jurnal Abdimas, 165-169. Yohana, C. (2014). Pelatihan Mengelola Keuangan Sederhana bagi Pengusaha Kecil di Desa Cibadak. Jurnal Sarwahita, 67-70. 